\title{
The Development of Teacher Professional Development Program for Communicative Language Teaching Using Community of Practice Approach in Thailand
}

\author{
Worawute Khunprathum* Denchai Prabjandee Chanphorn Prommas \\ Faculty of Education, Burapha University, Thailand
}

\begin{abstract}
The teacher professional development program for communicative language teaching using community of practice approach is the process of collaborating with teachers for exchanging knowledge, learning from past experiences, problem solving, and applying new knowledge to develop the teaching profession. The purpose of this research was to study the results of using a teacher professional development program for communicative language teaching using a community practice approach and then develop it further. The participants were teachers who were willing to participate in using the teacher professional development program. The teachers were interviewed with the same questions to evaluate the changes in communicative language teaching beliefs and communicative language teaching competencies to compare the competencies before and after using program. This research found that the participants held correct belief and conformed to communicative language teaching approach. Also, the development score of the evaluation of communicative language teaching competencies was higher than before using the program followed by a relative increase in score at a high level.
\end{abstract}

Keywords: Teacher Professional Development Program, Communicative Language Teaching, Community of Practice, Communicative Language Teaching Beliefs, Communicative Language Teaching Competencies

DOI: $10.7176 / \mathrm{JEP} / 11-33-16$

Publication date: November $30^{\text {th }} 2020$

\section{Introduction}

Teachers are the most important factor in achieving development in student's English proficiency as English is the key to natural learning, interacting, emulating, and having a good attitude towards learning and practicing. Therefore, developing teachers knowledge and communicative language teaching proficiency is very important and necessary for raising their teaching competency. (Tootkaboni, 2019, pp. 265-266).It is important for teachers to continue their professional development in order to meet ever-changing demands of education. The important skills are designed learning context, positive attitude for changing management, or improving themselves with support from other teachers. (Jeenawathana, 2016, p. 1379). Moreover, it is art, science, and the process of adults learning how to help them to learn. Experience and the ability to learn and apply knowledge or skills are desirable abilities for problem solving in real life. (Kasworm, Rose, \& Rose-Gordon, 2010, p. 42), (Corder, 2002, p. 61). It is important change to develop skill, knowledge and arguments in which knowledge and all experiences are interesting, and teacher's ability to learn for existing knowledge. (Rogers, 2002, p.104)

Therefore, the most suitable and interesting tactic is the community of practice approach because it involves a group of people who are interested in the same thing and participate in solving problems together to increase knowledge, professionalism, and learning new things. (Wenger, 1998, p. 75)

\subsection{Teacher Professional Development}

Teacher professional development is the process of developing skills and competencies for in order to further improve educational achievement (Hassel, 1999, p1). and it was designed for developing an educator's attitude to improve student's learning. (Guskey, 2000, p.14). Moreover, it is developed with the purpose of approaching professional practicing and increasing teaching efficiency. (Cambridge International Examinations, 2009, p.1). The important features of professional development include training, practicing new skills, researching, and learning from others past experiences. (Levin, 2014, p.1).

\subsection{Communicative Language Teaching}

CLT is a method that focuses on the ability to communicate of the students and integrates for 4 skills (listening, speaking, reading, and writing) to achieve this. Moreover, it gives students the opportunity have social interactions. The CLT's activity is centrally focused on children and flexibility of the content for teaching under context. In addition, the activity should provide learner's with language skills to communicate in class and in real-life.

\subsection{Community of Practice}

Community of practice is a group of the people who have the same objective to exchange experiences and interests in the group in order to develop and solve the problems together. (Wenger \& Snyder, 2000, p. 139) Learning and 
exchanging ideas to solve the problems from the members in the community of practice will help develop professionalism and allow group members to gain a deeper understanding by corroborating with each other.

\section{The study}

\subsection{Research Questions}

1. What are the processes and details of teacher professional development program for communicative language teaching using community of practice have?

2. Can teacher professional development program for communicative language teaching using community of practice change beliefs and increase teaching competencies of CLT?

\subsection{Research Design}

The development of teacher professional development program for communicative language teaching using community of practice approach is illustrated in figure 1 :

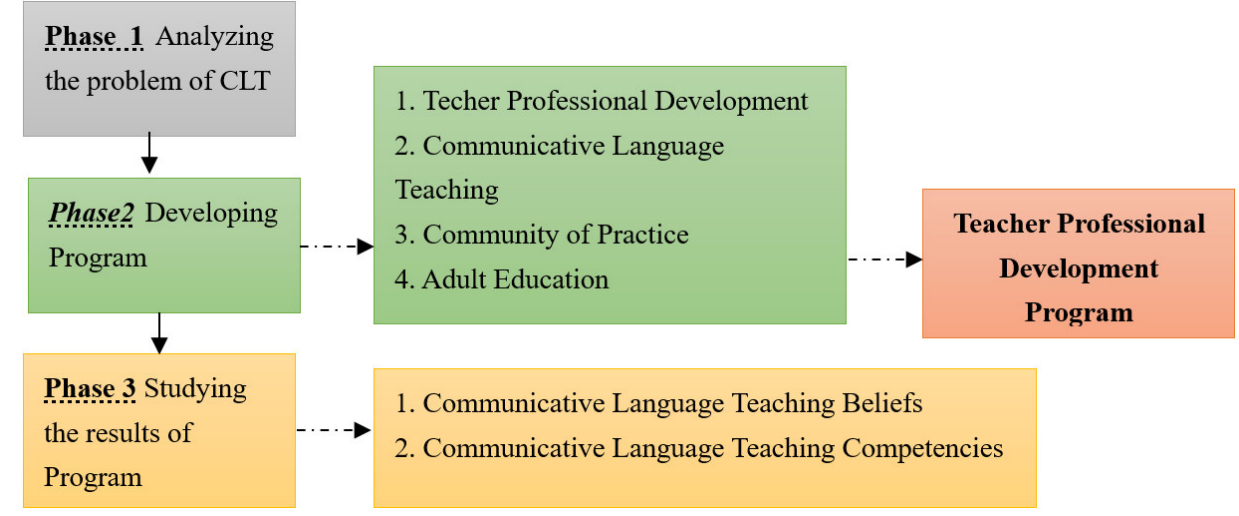

\subsection{Participants}

Figure 1. Flowchart of research design

The 5 participants were willing to participate and use teacher professional development program after it had been announced. Of the 5 participants one was a teacher who had taught English in the secondary school of Bantan district, Chaiyaphum province. Among the 2 male and 3 female participants, 1 was teaching in junior high school, 2 in senior high school, and 2 in junior and senior school. The age of the participants was around 22-30 and 31-40 years. 2 participants have graduated with Bachelor's degrees and 3 have Master's degree. 3 participants had teaching experience of around 1-5 years and 2 had teaching experience of around 6-10 years.

\subsection{Data Collection}

The participants were informed about the research and they understood the purpose of this research and were willing to participate. Six instruments were used for data collection: focus group interview form (the beliefs of CLT, sharing teaching experience, and teaching reflection), teacher professional development program. The evaluation form of teacher professional development program. And the evaluation form of competencies of teacher's CLT.

The participants were interviewed with the same questions and could freely show their opinions. The focus group interview about the statement of sharing teaching experience was the data used to develop the program. The beliefs of CLT have been interviewed before and after using the program to evaluate the changing in beliefs about CLT. The teaching reflections were discussed after finishing teaching in each lesson.

The evaluation form of competencies of teacher's CLT was the questionnaire. There was 5 Likert scale investigating their agreement with the statement and they were asked to compare the competencies before and after using program.

\subsection{Data Analysis}

The goal of analysis was to study teacher's change in beliefs and teaching competencies of communicative language teaching. The qualitative analysis was analyzed from the form of the focus groups interview using descriptive statistics (content analysis) with 6 issues of beliefs in communicative language teaching. The quantitative analysis was compared the competencies of teacher's communicative language teaching before and after using program. 


\section{Findings}

3.1 What are the processes and details of teacher professional development program for communicative language teaching using community of practice have?

The researcher used curriculum development approach to develop teacher professional development program for communicative language teaching using community of practice approach. The program follows the processes for practicing and processing to make the learning experience to increase students' learning efficiency with the learning purpose and suitable evaluation. The program has 5 important processes and details as follow;

1. Announcing and Grouping is the process of announcing and grouping the participants who are willing and interested in using teacher professional development program for communicative language teaching using community of practice.

2. Problem and Experience Exchanging is the process of exchanging problems and experiences from class with other participants in the group.

3. Activity Designing is designing the lesson plan under communicative language teaching activity for use in the classroom.

4. Proceeding is the process of using the lesson plan under communicative language teaching activity in the classroom and reviewing problems, results of activity, and issues for development.

5. Evaluating is the process of evaluating teacher beliefs and competencies about communicative language teaching.

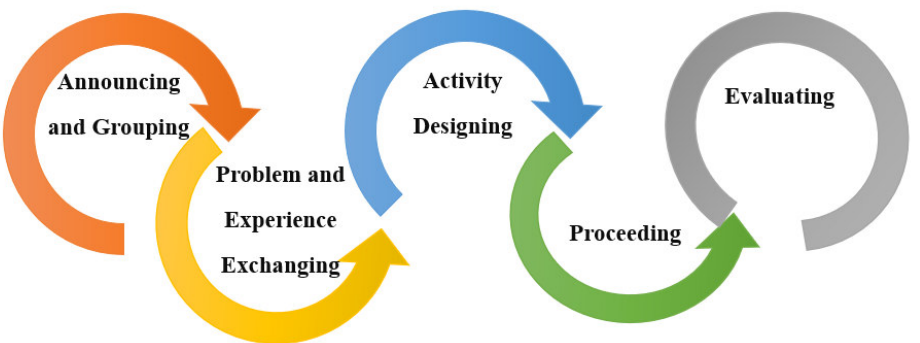

Figure 2. Process of teacher professional development for communicative language teaching using community of practice

3.2 Can teacher professional development program for communicative language teaching using community of practice change beliefs and increase teaching competencies of CLT?

The results from the group interview were analyzed with regards to teacher professional development program. There were two main issues to discuss as follows:

3.2.1 The Communicative Language Teaching Beliefs

The results indicated that there were changes in beliefs about communicative language teaching from the teachers in table 1. It shows that participants had changed their beliefs after using the program. There were 2 issues that remained unchanged due to the participants having the correct belief and conforming to communicative language teaching approach.

Table 1 The Communicative Language Teaching Beliefs

\begin{tabular}{|c|c|c|c|}
\hline No. & Communicative Language Teaching Beliefs & Change & $\begin{array}{c}\text { Not } \\
\text { Change }\end{array}$ \\
\hline \multicolumn{4}{|c|}{ 1. The context to use language for communication } \\
\hline 1.1 & Teacher belief on the context to use CLT efficiency. & $\sqrt{ }$ & \\
\hline 1.2 & Teacher belies on CLT can be used in the real-life & & $\sqrt{ }$ \\
\hline \multicolumn{4}{|c|}{ 2. The teacher's characteristic for CLT } \\
\hline 2.1 & Teacher belief on teacher's role & & $\sqrt{ }$ \\
\hline 2.2 & Teacher belief on error correction and assessment & $\sqrt{ }$ & \\
\hline \multicolumn{4}{|c|}{ 3. The experience of CLT } \\
\hline 3.1 & Teacher belief on facilitating to use language to communicate efficiency & $\sqrt{ }$ & \\
\hline 3.2 & Teacher belief on facilitating with student's need and different learning style & $\sqrt{ }$ & \\
\hline \multicolumn{4}{|c|}{ 4. The learning of language for communication } \\
\hline 4.1 & Teacher belief on CLT with memorizing & $\sqrt{ }$ & \\
\hline 4.2 & Teacher belief on the role and important of grammar & $\sqrt{ }$ & \\
\hline
\end{tabular}

3.2.2 The Communicative Language Teaching Competencies

The analysis of the communicative language teaching competencies in table 2 had a good level after using the teacher professional development program $(X=4.70, \mathrm{SD}=0.49)$. The development score of the communicative language teaching competencies was higher than before using the program followed by an increase of relative gain 
score at a high level (58.47).

Table 2 The development score of the communicative language teaching competencies

\begin{tabular}{c|c|c|c|c}
\hline Participants & $\begin{array}{c}\text { Before using } \\
\text { program }\end{array}$ & $\begin{array}{c}\text { After using } \\
\text { program }\end{array}$ & \multicolumn{2}{|c}{$\begin{array}{c}\text { Development } \\
\text { Score }\end{array}$} \\
\hline 1 & 80 & 97 & 7 & 85.00 \\
\hline 2 & 81 & 92 & 9 & 57.89 \\
\hline 3 & 80 & 89 & 45.00 & 51.85 \\
\hline 4 & 73 & 97 & 10 & 52.63 \\
\hline 5 & 81 & 91 & $\mathbf{1 0 . 2 0}$ & $\mathbf{5 8 . 4 7}$ \\
\hline Average & $\mathbf{7 9 . 0 0}$ & $\mathbf{9 3 . 2 0}$ &
\end{tabular}

\section{Conclusion}

\subsection{The Communicative Language Teaching Beliefs}

There are 2 issues that teachers had not changed in their beliefs. First, they understand and believe that communicative language teaching in the classroom is the basis for using language to communicate in real-life such as occupations and studying at a high level. Then, they believe that the teacher's role in communicative language teaching is a facilitator. Teachers will support, promote, and engage students in practicing and communicating efficiently. (Littlewood, 1981, p.19) , (Richard, 2006, pp.22-23). The figures above show that teachers correctly understand because their beliefs conform to communicative language teaching approach. Moreover, they still have a positive belief about communicative language teaching although they have not made an activity in the classroom yet. (Nishino, 2009, Abstract).

They had changed their belief that there is no limitation for the context of communication. Teachers are able to be the context managers in class, design interesting activities, make a suitable classroom atmosphere, and provide student's learning. Teachers had changed their teaching not only in grammar translation or structure but they change the focus to an activity to promote students to communicate purposefully. (Littlewood, 1981, pp. 2021). Also, before using the program teachers demonstrated a belief that all activities are suitable for all students, which was incorrect. After they used the program, they had changed their belief now finding that they must design an activity to cater to the needs and different learning styles of students. (Richard, 2006, pp. 22-23).

\subsection{The Communicative Language Teaching Competencies}

Teachers had changed and increased their communicative language teaching competencies. They had focused the purpose and goal of designing an activity with child-center for allowing students to show their competency to use language purposefully. (Littlewood, 1981, pp. 20-21), (Richard, 2006, pp. 22-23). The results of changing their competencies with regards to designing activities to support students to analyze and summarize in each issue because students have an important role in the classroom. (Chamaipak \& Barnard, 2010, pp. 291-295) (Freeman, 2000, p.121).

Teachers had changed to correct students' errors while they are practicing or using language to communicate because it is disturbing and interrupts them which results in nervousness and and a lack in confidence when using language. (Littlewood, 1981, p. 19). Teachers were able to correct errors at the end of the activity in either as a class or on an individual level to specifically target errors in order to use language to communicate correctly.

\section{References}

Cambridge International Examination. (2015, November). Professional Development of Teacher. Retrieved From https://www.cambridgeinternational.org/images/122975-cambridge-professionalbrochure.pdf

Chamaipak. T., \& Barnard. R. (2010). Language Teachers' Beliefs and Practices Regarding the Appropriateness of Communicative Methodology: A Case Study from Thailand. The journal of Asia TEFL, 7(2), 279-311.

Freeman, D. L. (2000). Techniques and Principles in Language Teaching. New York: Oxford University Press.

Guskey, T.R. (2000). Evaluating Professional Development. Thousand Oaks, CA: Corwin Press.

Guskey, T.R. (2002). Professional Development and Teacher Change, Teachers and Teaching, 8(3/4), 381-391.

Hassel, E. (1999). Professional Development: Learning From the Best. Illinois: North Central Regional Educational Laboratory.

Jeenawathana, A. (2016). Self- Development of Professional Teacher. Veridian E-Journal, Silpakorn University. $9(2), 1379-1395$.

Kasworm, C. E., Rose, A. D., \& Rose-Gordon, J. M. (2010). Handbook of adult and continuing education. California: SAGE

Levin, B. (2014). Professional Development and the Promotion of Highly-Effective Teaching. Retrieved from https://iei.ncsu.edu/wp-content/uploads/2014/02/Professional-Development-FP.pdf

Littlewood, W. (1981). Communicative language teaching: An introduction. Cambridge: Cambridge University 
Press.

Nishino, T. (2009). Communicative Language Teaching in Japanese High Schools: Teachers' Beliefs and Classroom Practices. Doctoral dissertation, Faculty of Education, Temple University.

OECD. (2009). Creating Effective Teaching and Learning Environments. First Results from TALIS.

Paris:OECD Publications <http://www.oecd.org/dataoecd/ 17/51/43023606.pdf.

Richards, J. C. (2006). Communicative Language Teaching Today. Cambridge: Cambridge University Press.

Tootkaboni, A. A. (2019). Teachers' beliefs and practices toward communicative language teaching in the expanding circle. Revista Signos, 52(100), 265-289. doi: 10.4067/S0718-09342019000200265.

Wenger, E. (1998). Community of practice: Learning, meaning, and identity. New York, Cambridge University Press.

Wenger, E. C. \& Snyder, W. M. (2000). Communities of Practice: The Organizational Frontier. Retrieved from http://www.rareplanet.org/sites/rareplanet.org/files/Communities_of_Practice The_Organizational Organizational Frontier\%5B1\%5D.pdf. 